ISSN 1392-3196 / e-ISSN 2335-8947

Zemdirbyste-Agriculture, vol. 102, No. 2 (2015), p. 141-146

DOI $10.13080 /$ z-a.2015.102.018

\title{
The bio-organic nano fertilizer improves sugar beet photosynthesis process and productivity
}

\author{
Elena JAKIENE $\dot{1}^{1}$, Vidmantas SPRUOGIS² ${ }^{2}$ Kęstutis ROMANECKAS ${ }^{3}$, \\ Anželika DAUTARTE் ${ }^{2}$, Dovilè AVIŽIENYTE் $\dot{E}^{3,4}$ \\ ${ }^{1}$ Institute of Agriculture and Food Science, Aleksandras Stulginskis University \\ Studentų 11, Akademija, Kaunas distr., Lithuania \\ ${ }^{2}$ Institute of Environment and Ecology, Aleksandras Stulginskis University \\ ${ }^{3}$ Institute of Agroecosystems and Soil Sciences, Aleksandras Stulginskis University \\ E-mail: kestas.romaneckas@asu.lt
}

${ }^{4}$ Rumokai Experimental Station, Lithuanian Research Centre for Agriculture and Forestry Rumokai, Vilkaviškis distr., Lithuania

\begin{abstract}
Applications of biological agents intensify the growth of crops, so they more quickly form a maximum leaf area, optimize photosynthesis, increase plant productivity and quality. Chemical producers offer a new generation of bio-organic fertilizers based on nano technologies. Such fertilizers have not been well investigated yet; therefore, the aim of this study was to ascertain the influence of the fertilization rates by bio-organic nano fertilizer, made from cattle manure on the effectiveness of sugar beet crop photosynthesis and productivity parameters. The investigations were carried out in 2011-2012 at Aleksandras Stulginskis University's Research Station, Kaunas district, Lithuania $\left(54^{\circ} 52^{\prime} \mathrm{N}, 23^{\circ} 49^{\prime} \mathrm{E}\right)$ on a silty loam Luvisol (Calcari-Epihypogleyic Luvisol, LVg-p-w-cc). Sugar beet plants were sprayed with the fertilizer at doses of 0.5 or $1.0 \mathrm{~L} \mathrm{ha}^{-1}$ at the BBCH 18 and/or BBCH 31 stages. Single application of the bio-organic fertilizer at single $1 \mathrm{~L} \mathrm{ha}^{-1}$ dose was more effective than at single $0.5 \mathrm{~L} \mathrm{ha}^{-1}$ or double $0.5+0.5 \mathrm{~L} \mathrm{ha}^{-1}$ doses. At the beginning of intensive sugar beet development (BBCH 37-38), single $1 \mathrm{~L} \mathrm{ha}^{-1}$ dose increased the number of leaves by $19.6 \%$, leaf area by $13.4 \%$, root diameter by $11.1 \%$, canopy dry biomass by $29.1 \%$, root biomass by $42.6 \%$, net photosynthetic productivity by $15.8 \%$, root yield by $12.6 \%$, sucrose content by 1.03 percentage points and yield of white sugar by $19.2 \%$ in comparison with the untreated beets. Double $1+1 \mathrm{~L}$ $\mathrm{ha}^{-1}$ dose of fertilizer was slightly more effective but economically less suitable than single $\left(1 \mathrm{~L} \mathrm{ha}^{-1}\right)$. In general, the application of bio-organic fertilizer revealed a great potential for optimization of sugar beet development, productivity and quality parameters.
\end{abstract}

Key words: Beta vulgaris, biometric and growth parameters, sucrose content, yield.

\section{Introduction}

In order to optimize the productivity of field crops, optimal conditions for the growth of plants need to be created that will accelerate the vital processes occurring in plants and affect crop productivity. However, plants are affected by negative factors that cause stress. Negative factors affecting sugar beet growth can lead to the stress caused by drought, diseases, pests and weeds (herbicides). It should be noted that stress tolerant sugar beet varieties are less fertile under optimal growth conditions (Pidgeon et al., 2006). Shen et al. (2013) confirmed that application of bio-organic fertilizers could more effectively control Fusarium wilt disease. In Lithuanian climate conditions, sugar beets are affected by more than one hundred different species of pests. Due to pest damage, sugar beet seed germination can be reduced by $47-74 \%$ and yield by up to $24 \%$ (Pekarskas, 2008).
Sugar beets cannot tolerate shading by weeds because they grow slowly during the early stages (6-8 weeks after sowing) of development. However, growth of weeds should be suppressed until harvest (Dewar et al., 2006). Sugar beets can be damaged by herbicides from direct spraying, be susceptible to herbicides brought by the wind or sprayed on adjacent crops or even by cultivating sugar beet after other plants that had been sprayed with herbicides, because they remain in the soil for a long time. Various stresses can be mitigated by applying macro-and micronutrient solutions, biological preparations or bioorganic fertilizers (Jakienè et al., 2009; Ghormade et al., 2011).

Optimization of photosynthetic parameters by technological measures also directly determines productivity (Lawlor, 1995). The photosynthetic 
productivity of sugar beet mainly depends on varietal differences, leaf assimilation area and spatial distribution, the inclination angle of the sunshine, photosynthetic pigment content (Suojala, 2000; Jakiene et al., 2008). Farmers have mostly tried to increase plant productivity by applying abundant nitrogen fertilization, and unreasonable amounts of plant protection products (Šiuliauskas et al., 2008). Eventually, the soil starts to degrade. Biological agents may promote soil biological processes and increase plant productivity and production quality because they more quickly attain a maximum leaf area, have more intensive photosynthesis; rapid assimilate transport from the leaves to the roots (Staugaitis, Laure, 2008; Romaneckas, Romaneckienè, 2009). The efficiency of bio-organic fertilizers is especially apparent under adverse growth conditions. However, the application of bio-organic or bio-organic nano fertilizers is not well documented. So, the aim of our research was to estimate the influence of fertilization rates of such bio-organic fertilizer on sugar beet development, photosynthetic parameters, yield and quality of roots.

\section{Material and methods}

Description of experimental site and soil Investigations were carried out in 2011-2012 at Aleksandras Stulginskis University's Research Station, Kaunas district, Lithuania $\left(54^{\circ} 52^{\prime} \mathrm{N}, 23^{\circ} 49^{\prime}\right.$ E) on silty loam Luvisol (Calcari-Epihypogleyic Luvisol, LVg$p-w-c c)$. The $\mathrm{pH}_{\mathrm{KCl}}$ of the arable soil layer was 7.17.3, available phosphorus $\left(\mathrm{P}_{2} \mathrm{O}_{5}\right)-238-315 \mathrm{mg} \mathrm{kg}^{-1}$, available potassium $\left(\mathrm{K}_{2} \mathrm{O}\right)-154-172 \mathrm{mg} \mathrm{kg}^{-1}$, humus - 17.0-24.5 $\mathrm{g} \mathrm{kg}^{-1}$. In the experiment, sugar beet plants were sprayed with different doses of bio-organic nano fertilizer. Treatments consisted of: 1) C-0 - control, without bio-organic fertilizer, 2) $\mathrm{N}-0.5-1$ - bio-organic fertilizer $0.5 \mathrm{~L} \mathrm{ha}^{-1}$ at $\left.\mathrm{BBCH} 18,3\right) \mathrm{N}-0.5-2$ - bio-organic fertilizer $0.5 \mathrm{~L} \mathrm{ha}^{-1}$ at BBCH 18 and 31, 4) N-1-1 - bioorganic fertilizer $1 \mathrm{~L} \mathrm{ha}^{-1}$ at BBCH 18 and 5) N-1-2- bioorganic fertilizer $1 \mathrm{~L} \mathrm{ha}^{-1}$ at BBCH 18 and 31 .

The initial experimental plot area was $12.6 \mathrm{~m}^{2}$. The experiment was carried out in four replications; a randomized plot design was applied. The pre-crop of sugar beet was winter wheat. In the spring, the soil was cultivated and all experimental plots were primarily fertilized by fertilizer NPK 8:20:30 at $300 \mathrm{~kg} \mathrm{ha}^{-1}$ rate $\left(\mathrm{N}_{24+38} \mathrm{P}_{60} \mathrm{~K}_{90}\right)$. The herbicide Pyramin Turbo (5.0 L ha-1, a.i. chloridazon $520 \mathrm{~g} \mathrm{~L}^{-1}$ ) was applied before sowing. The soil was tilled repeatedly by a complex cultivator. A sugar beet variety 'Ernestina' (by KWS, Germany) was sown. In early May, upon renewed weed germination, the field was sprayed with the herbicide Betanal Expert (1.30 $\mathrm{L} \mathrm{ha}^{-1}$, a.i. ethofumezate $112 \mathrm{~g} \mathrm{~L}^{-1}$, phenmedipham $91 \mathrm{~g} \mathrm{~L}^{-1}$ and desmedipham $71 \mathrm{~g} \mathrm{~L}^{-1}$ ). The sugar beet crop was additionally fertilized with ammonium nitrate $\left(\mathrm{N}_{34}\right) 112 \mathrm{~kg} \mathrm{ha}^{-1}$ before leaves covered $70-80 \%$ of the ground. Bio-organic fertilizer was applied according to the scheme of the experiment. The amount of water for fertilizer solution was $250 \mathrm{~L} \mathrm{ha}^{-1}$. Weeds were repeatedly controlled using a herbicide mixture: Betanal Expert $\left(1.1 \mathrm{~L} \mathrm{ha}^{-1}\right)+\operatorname{Lontrel}\left(0.3 \mathrm{~L} \mathrm{ha}^{-1}\right.$, a.i. clopyralid $\left.300 \mathrm{~g} \mathrm{~L}^{-1}\right)$.
Samples for sugar beet productivity and quality evaluation were collected at the beginning of October.

Methods. Sugar beet leaf area was measured using a leaf area measurement system WinDIAS 3 (Delta-T Devices, UK). The dry matter of sugar beet plants was determined by drying them at $105^{\circ} \mathrm{C}$ temperature to a constant weight. Net photosynthetic efficiency during sugar beet vegetation was calculated according to the formula:

$$
\mathrm{F}_{\mathrm{pr}}=\mathrm{M}_{2}-\mathrm{M}_{1} / 1 / 2\left(\mathrm{~L}_{0}+\mathrm{L}_{1}\right) \times \mathrm{T},
$$

where $\mathrm{F}_{\mathrm{pr}}$ is photosynthesis productivity, $\mathrm{g} \mathrm{cm}^{-2}$ per $24 \mathrm{~h}, \mathrm{M}_{2}$ and $\mathrm{M}_{1}$ - dry weight gain over a period of time, $\mathrm{g}, \mathrm{L}_{0}$ and $\mathrm{L}_{1}$ - leaf area at the beginning and end of a period, $\mathrm{cm}^{2}$, and $\mathrm{T}-$ period in days. Sugar beet yield was determined by weighing the roots from each plot and was converted to $\mathrm{Mg} \mathrm{ha} \mathrm{h}^{-1}$. Sugar beet roots were counted, weighed and the number of plants per hectare was estimated. Samples (25 roots) for estimation of sucrose content were taken from each experimental plot. Sucrose content was evaluated at the Marijampole sugar factory, Lithuania. Quantity of white sugar (Ws, $\mathrm{Mg} \mathrm{ha}^{-1}$ ) was calculated according to the formula:

$\mathrm{Ws}=\mathrm{Y} \times \mathrm{Sa}$, where $\mathrm{Y}$ is yield of roots $\mathrm{Mg} \mathrm{ha}^{-1}$, $\mathrm{Sa}$ - sugar output, \%;

$\mathrm{Sa}=\mathrm{Sc}-0.9-3.76$, where $\mathrm{Sc}$ is sucrose content, $\%, 0.9$ - average sugar losses before molasses, $\%, 3.76-$ average sugar loses in molasses, $\%$.

Research data was analyzed with a statistical computer program ANOVA from the package SELECTION. The treatment effect was tested by the $P$ test. If $P \leq 0.050>0.010$, the differences from the control treatment are significant at $95 \%$ probability level, and if $P>0.050$, there are no significant differences.

The bio-organic universal nano fertilizer Nagro was investigated. It is an ecologically safe fertilizer made from cattle manure (by the method of cold synthesis) with micro-, macro- and mezo-elements and bioactive materials. It is suitable for fertilization of all types of agricultural crops, ornamental crops, forests and parks, and green plots in various types of soils. According to the producers (Russian Federation), the use of the fertilizer increases yields, enhances plant immunity, protects against stress (drought, frost, pesticide effects), and disease, shortens the ripening period and improves product quality. It is used as a water solution for seed treatment before sowing, or as foliar application. The composition of the fertilizer is: humus extract, humic and fulvic acids - not less than $0.2 \%$, total nitrogen $(\mathrm{N})$ - not less than $0.015 \%$, total potassium $\left(\mathrm{K}_{2} \mathrm{O}\right)$ - not less than $0.02 \%$, total phosphorus $\left(\mathrm{P}_{2} \mathrm{O}_{5}\right)-$ not less than $0.002 \%$. The microelements boron (B), copper $(\mathrm{Cu})$, zinc $(\mathrm{Zn})$, cobalt $(\mathrm{Co})$, magnesium $(\mathrm{Mg})$, manganese $(\mathrm{Mn})$, molybdenum (Mo), and iron $(\mathrm{Fe})$ are included too.

Meteorological conditions. The weather conditions during the growing season affect the chemical composition of sugar beet: a lack of moisture slows down fat synthesis and increases the protein quantitatively; increasing rainfall, when the air temperature lowers, produces more intense carbohydrate synthesis in the leaves. The meteorological conditions during sugar beet vegetation were mostly warmer than usual (Table 1). 
Table 1. Average air temperatures and rainfall during sugar beet vegetation (the data of Kaunas Meteorological Station)

\begin{tabular}{lccccccc}
\hline \multicolumn{1}{c}{ Index / month } & April & May & June & July & August & September & October \\
\hline & \multicolumn{7}{c}{2011} \\
\hline Temperature ${ }^{\circ} \mathrm{C}$ & 8.9 & 13.1 & 18.1 & 19.6 & 18.1 & 13.6 & 7.7 \\
Rainfall mm & 25.2 & 46.9 & 82.7 & 144.0 & 152.4 & 73.9 & 21.6 \\
\hline \multicolumn{7}{c}{2012} \\
\hline Temperature ${ }^{\circ} \mathrm{C}$ & 7.7 & 13.7 & 15.3 & 19.4 & 17.1 & 13.3 & 7.6 \\
Rainfall mm & 72.3 & 50.3 & 93.4 & 112.8 & 69.2 & 67.2 & 75.0 \\
\hline & \multicolumn{7}{c}{ Long-term (since 1974) average } \\
\hline Temperature ${ }^{\circ} \mathrm{C}$ & 6.7 & 12.6 & 15.6 & 17.6 & 17.1 & 12.2 & 7.1 \\
Rainfall mm & 38.1 & 47.2 & 66.7 & 83.0 & 73.2 & 53.8 & 54.7 \\
\hline
\end{tabular}

The precipitation rate was variable and uneven during the two experimental years. In 2011, April was drier than the long-term average and May was similar to typical conditions; however, the summer months and September were too wet (especially July and August). These factors had a negative effect on beet growth. October was dry and there was a favourable period for sucrose accumulation in the roots. In 2012, the entire growing season was more humid than usual. The only exception was in August. Under those conditions in heavy soils some sugar beet plants died because of too high water content in the soil.

\section{Results and discussion}

Sugar beet biometric parameters. Sabir et al. (2014) indicated that application of the nano Cabased fertilizer led to a significant increase in foliar development and chlorophyll concentration of the vines. In Moghaddasi et al. (2013) experiments, Zn nanoparticles were produced from ground rubber and they were more effective than $\mathrm{Zn}$-sulphate for cucumber. In our experiment, the bio-organic fertilizer with nano multi microelement complex mostly had a significant positive impact on sugar beet growth and development processes. Biometric measurements, carried out at the BBCH 34-35 growth stages, showed that sugar beet leaf growth was increased by a higher level of fertilization (1-2 $\left.\mathrm{L} \mathrm{ha}^{-1}\right)$. Fertilized seedlings had significantly more (by the 12.6$23.2 \%$ ) leaves than untreated plants (Table 2 )

The greatest effect was obtained by applying N-1-2 treatment. Similarly Kumar et al. (2014) found, that double dose of bio-fertilizers increased wheat root and shoot length, number of roots and leaves, green and dry mass of roots and canopy. The biometric measurements in BBCH 37-38 stages showed similar results (Table 2). Fertilization level of bio-organic fertilizer from 1 to 2 $\mathrm{L} \mathrm{ha}^{-1}$ significantly increased the number of sugar beet leaves by $17.4-27.6 \%$. As in $\mathrm{BBCH} 34-35$, treatment N-1-2 was the most effective. In the BBCH 34-35 growth stage, foliar fertilization significantly increased the diameter of roots by $5.4-16.3 \%$ (Table 2 ). The highest root diameter was obtained in the treatment N-1-2. In the later sugar beet growth stages (BBCH 37-38) we found analogous results.

Table 2. Effect of different fertilization rates on sugar beet biometric parameters (the average data of 2011-2012)

\begin{tabular}{|c|c|c|c|c|c|c|}
\hline \multirow{3}{*}{ Treatment } & \multicolumn{3}{|c|}{ Quantity of leaves } & \multicolumn{3}{|c|}{ Diameter of root } \\
\hline & \multirow{2}{*}{$\begin{array}{c}\text { number per } \\
\text { plant }\end{array}$} & \multicolumn{2}{|c|}{ \pm from control } & \multirow{2}{*}{$\mathrm{cm}$} & \multicolumn{2}{|c|}{ \pm from control } \\
\hline & & number & $\%$ & & $\mathrm{~cm}$ & $\%$ \\
\hline \multicolumn{7}{|c|}{ BBCH 34-35 stages } \\
\hline $\mathrm{C}-0$ & 19.8 & - & - & 9.2 & - & - \\
\hline N-0.5-1 & 20.6 & 0.8 & 4.0 & $9.7 *$ & 0.5 & 5.4 \\
\hline $\mathrm{N}-0.5-2$ & $23.5^{*}$ & 3.7 & 18.7 & $10.3^{*}$ & 1.1 & 12.0 \\
\hline N-1-1 & $22.3^{*}$ & 2.5 & 12.6 & $10.0 *$ & 0.8 & 8.7 \\
\hline $\mathrm{N}-1-2$ & $24.4^{*}$ & 4.6 & 23.2 & $10.7^{*}$ & 1.5 & 16.3 \\
\hline $\mathrm{LSD}_{05}$ & 1.13 & \multicolumn{5}{|c|}{0.50} \\
\hline \multicolumn{7}{|c|}{ BBCH 37-38 stages } \\
\hline $\mathrm{C}-0$ & 27.5 & - & - & 11.7 & - & - \\
\hline $\mathrm{N}-0.5-1$ & $29.7 *$ & 2.2 & 8.0 & $12.7^{*}$ & 1.0 & 8.6 \\
\hline $\mathrm{N}-0.5-2$ & $32.3 *$ & 4.8 & 17.4 & $13.1 *$ & 1.4 & 12.0 \\
\hline N-1-1 & $32.9 *$ & 5.4 & 19.6 & $13.0^{*}$ & 1.3 & 11.1 \\
\hline N-1-2 & $35.1 *$ & 7.6 & 27.6 & $13.6^{*}$ & 1.9 & 16.2 \\
\hline $\mathrm{LSD}_{05}$ & 1.57 & & & 0.64 & & \\
\hline
\end{tabular}

C-0 - control, without bio-organic fertilizer, N-0.5-1 - bio-organic fertilizer $0.5 \mathrm{~L} \mathrm{ha}^{-1}$ at BBCH 18, N-0.5-2 - bio-organic fertilizer $0.5 \mathrm{~L} \mathrm{ha}^{-1}$ at BBCH 18 and 31, N-1-1 - bio-organic fertilizer $1 \mathrm{~L} \mathrm{ha}^{-1}$ at BBCH 18, N-1-2- bio-organic fertilizer $1 \mathrm{~L} \mathrm{ha}^{-1}$ at BBCH 18 and $31{ }^{*}$ - significant difference from control treatment (C-0) at $P \leq 0.05$ 
Sugar beet growth parameters. The application of bio-organic fertilizer significantly increased leaf area of sugar beet plants (Table 3). In BBCH 34-35 growth stages, single or double application of fertilizer in lower concentrations (N-0.5-1 and N-0.5-2) increased average leaf area by $7.7-8.4 \%$. More effective was fertilizer application at the higher concentrations (N-1-1 and $\mathrm{N}-1-2)$. Sugar beet leaf area increased by $12.2-13.7 \%$ compared to the control treatment (Table 3 ).

Table 3. Effect of different fertilization rates on sugar beet leaf area and dry biomass (the average data of 20112012)

\begin{tabular}{|c|c|c|c|c|c|c|c|c|c|}
\hline \multirow{3}{*}{ Treatment } & \multicolumn{3}{|c|}{ Leaf area } & \multicolumn{3}{|c|}{ Canopy biomass } & \multicolumn{3}{|c|}{ Root biomass } \\
\hline & \multirow{2}{*}{$\begin{array}{c}\mathrm{cm}^{2} \text { per } \\
\text { plant }\end{array}$} & \multicolumn{2}{|c|}{ \pm from control } & \multirow{2}{*}{$\begin{array}{l}\text { g per } \\
\text { plant }\end{array}$} & \multicolumn{2}{|c|}{ \pm from control } & \multirow{2}{*}{$\begin{array}{l}\text { g per } \\
\text { plant }\end{array}$} & \multicolumn{2}{|c|}{ \pm from control } \\
\hline & & $\mathrm{cm}^{2}$ & $\%$ & & $\mathrm{~g}$ & $\%$ & & $\mathrm{~g}$ & $\%$ \\
\hline \multicolumn{10}{|c|}{ BBCH 34-35 stages } \\
\hline $\mathrm{C}-0$ & 3793.9 & - & - & 34.4 & - & - & 21.5 & - & - \\
\hline $\mathrm{N}-0.5-1$ & $4086.8^{*}$ & 292.9 & 7.7 & $36.6^{*}$ & 2.2 & 6.4 & $24.8^{*}$ & 3.3 & 15.4 \\
\hline $\mathrm{N}-0.5-2$ & $4111.0 *$ & 317.1 & 8.4 & $37.1 *$ & 2.7 & 7.8 & $26.4^{*}$ & 4.9 & 22.8 \\
\hline N-1-1 & $4257.7^{*}$ & 463.8 & 12.2 & $43.9^{*}$ & 9.5 & 27.6 & $30.4^{*}$ & 8.9 & 41.4 \\
\hline $\mathrm{N}-1-2$ & $4313.8 *$ & 519.9 & 13.7 & $44.7 *$ & 10.3 & 29.9 & $32.0 *$ & 10.5 & 48.8 \\
\hline $\mathrm{LSD}_{05}$ & 209.23 & & & 2.08 & & & 1.40 & & \\
\hline \multicolumn{10}{|c|}{ BBCH 37-38 stages } \\
\hline $\mathrm{C}-0$ & 7365.9 & - & - & 66.3 & - & - & 40.8 & - & - \\
\hline N-0.5-1 & $7951.4^{*}$ & 585.5 & 8.0 & 69.1 & 2.8 & 4.2 & $47.3 *$ & 6.5 & 15.9 \\
\hline $\mathrm{N}-0.5-2$ & $8134.2 *$ & 768.3 & 10.4 & 69.8 & 3.5 & 5.3 & $48.9^{*}$ & 8.1 & 19.8 \\
\hline N-1-1 & $8354.7 *$ & 988.8 & 13.4 & $85.6^{*}$ & 19.3 & 29.1 & $58.2 *$ & 17.4 & 42.6 \\
\hline N-1-2 & $8452.4 *$ & 1086.5 & 14.8 & $87.5^{*}$ & 21.2 & 32.0 & $61.5^{*}$ & 20.7 & 50.7 \\
\hline $\mathrm{LSD}_{05}$ & 404.38 & & & 4.45 & & & 2.70 & & \\
\hline
\end{tabular}

Explanations under Table 2

Application of bio-organic fertilizer solutions also resulted in significantly greater accumulation of dry matter in the beet canopy and roots (Table 3). 14 days after spraying with fertilizer solutions, the dry matter content in sugar beet leaves increased by $6.4-7.8 \%$ in those sprayed with single or double doses of fertilizer at lower concentrations (N-0.5-1 and N-0.5-2), and by $27.6-29.9 \%$ in those sprayed at higher concentrations (N-1-1 and N-1-2) compared to the dry matter content in untreated leaves. The bio-organic fertilizer initiated a higher dry matter quantity in the sugar beet roots too. Concentrations $\mathrm{N}-0.5-1$ and $\mathrm{N}-0.5-2$ resulted in an increase in the dry matter content in roots by $15.4-22.8 \%$, and N-1-1 and N-1-2 - by $41.4-48.8 \%$ compared to the control treatment. So the concentrations N-1-1 and N-12 were the most effective. Investigations repeated after three weeks (BBCH 37-38) showed similar results.

Photosynthesis productivity. In Sortino et al. (2012) experiment, bio-organic fertilizer from municipal wastes (kitchen wastes, home gardening residues and public park trimmings) with alkali demonstrated the best results in leaf chlorophyll content, plant growth and tomato fruit ripening rate and yield. In our experiment, application of the bio-organic fertilizer solutions also intensified photosynthesis in sugar beets. Application of investigated fertilizer at lower concentrations (N-0.5-1 and $\mathrm{N}-0.5-2$ ) increased net photosynthesis productivity insignificantly - by about $2 \%$, compared to the control treatment (Fig.).

Significantly higher net photosynthesis productivity was estimated after spraying higher concentrations (N-1-1 and N-1-2) of fertilizer. It increased by $15.8 \%$ and $18.4 \%$ compared to that in the control sugar beet plots. It should be noted that double application of higher doses

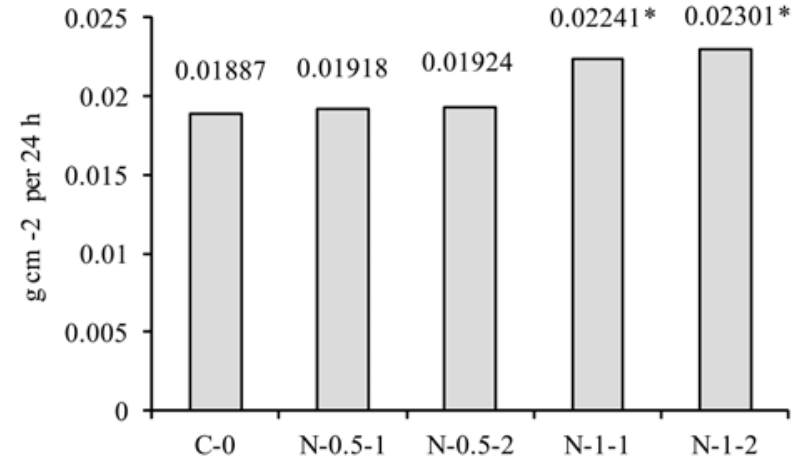

Explanations under Table 2; $\mathrm{LSD}_{05}=0.00125$

Figure. Effect of different fertilization rates on the sugar beet net photosynthesis productivity (the average data of 2011-2012)

(N-1-2) of fertilizer significantly increased photosynthesis productivity compared with single (N-1-1).

Sugar beet productivity parameters. The bioorganic fertilizer had a significant positive effect on sugar beet root yield (Table 4). The most effective were N-1-1 and N-1-2 treatments; however, the differences between them were insignificant.

In our experiment, the sugar beet crop density was similar - from 83.5 to 85.3 thousand plants per ha or varied from -0.6 to $1.3 \%$. Despite that, the average mass of root increased significantly by $3.9 \%$ to $14.6 \%$. Solutions of higher concentration (N-1-1 and N-1-2) were the most effective (Table 4).

Sugar beet root quality parameters. Salama et al. (2015) found the best quality parameters of fennel plants, when they were processed with $50 \%$ NPK $+50 \%$ organic fertilizer and bio-fertilizer. Similar results were 
Table 4. Effect of different fertilization rates on sugar beet productivity parameters (the average data of 2011-2012)

\begin{tabular}{|c|c|c|c|c|c|c|c|c|c|}
\hline \multirow{3}{*}{ Treatment } & \multicolumn{3}{|c|}{ Root yield } & \multicolumn{3}{|c|}{ Crop density } & \multicolumn{3}{|c|}{ Average mass of root } \\
\hline & \multirow{2}{*}{$\mathrm{Mg} \mathrm{ha}^{-1}$} & \multicolumn{2}{|c|}{ \pm from control } & \multirow{2}{*}{$\mathrm{tha}^{-1}$} & \multicolumn{2}{|c|}{ \pm from control } & \multirow{2}{*}{$\mathrm{kg}$} & \multicolumn{2}{|c|}{ \pm from control } \\
\hline & & $\mathrm{Mg} \mathrm{ha}^{-1}$ & $\%$ & & $\mathrm{t} \mathrm{ha}^{-1}$ & $\%$ & & $\mathrm{~kg}$ & $\%$ \\
\hline $\mathrm{C}-0$ & 64.50 & - & - & 84.2 & - & - & 0.766 & - & - \\
\hline N-0.5-1 & $67.92 *$ & 3.42 & 5.3 & 85.3 & 1.1 & 1.3 & $0.796^{*}$ & 0.030 & 3.9 \\
\hline $\mathrm{N}-0.5-2$ & $70.38 *$ & 5.88 & 9.1 & 83.7 & -0.5 & -0.6 & $0.841 *$ & 0.080 & 9.8 \\
\hline N-1-1 & $72.63 *$ & 8.13 & 12.6 & 83.5 & -0.7 & -0.8 & $0.878 *$ & 0.110 & 14.6 \\
\hline$N-1-2$ & $73.79 *$ & 9.29 & 14.4 & 84.8 & 0.6 & 0.7 & $0.878^{*}$ & 0.110 & 14.6 \\
\hline $\mathrm{LSD}_{05}$ & 1.803 & & & 3.45 & & & 0.0213 & & \\
\hline
\end{tabular}

Explanations under Table 2

found in investigations with broccoli (Naguib et al., 2012). In our experiment, application of bio-organic nano fertilizer at different doses increased the sucrose content in sugar beet roots significantly by $0.81-1.14$ percentage units (Table 5). The best treatment was $\mathrm{N}-1-2$, but $\mathrm{N}-0.5-$ 1 also showed similar results.

Table 5. Effect of different fertilization rates on sugar beet root quality parameters (the average data of 2011-2012)

\begin{tabular}{|c|c|c|c|c|c|}
\hline \multirow[b]{2}{*}{ Treatment } & \multicolumn{2}{|c|}{ Sucrose content } & \multicolumn{3}{|c|}{ Yield of white sugar } \\
\hline & $\%$ & $\begin{array}{c} \pm \text { from control } \\
\% \text { units }\end{array}$ & $\mathrm{Mg} \mathrm{ha}^{-1}$ & $\begin{array}{l} \pm \text { from control } \\
\mathrm{Mg} \mathrm{ha}^{-1}\end{array}$ & \pm from control $\%$ \\
\hline $\mathrm{C}-0$ & 16.65 & - & 8.28 & - & - \\
\hline $\mathrm{N}-0.5-1$ & $17.46^{*}$ & 0.81 & $9.42 *$ & 1.14 & 13.7 \\
\hline $\mathrm{N}-0.5-2$ & $17.64 *$ & 0.99 & $9.84 *$ & 1.56 & 18.8 \\
\hline N-1-1 & $17.68 *$ & 1.03 & $9.89 *$ & 1.61 & 19.2 \\
\hline$N-1-2$ & $17.79 *$ & 1.14 & $10.18^{*}$ & 1.90 & 22.9 \\
\hline $\mathrm{LSD}_{05}$ & \multicolumn{2}{|c|}{0.446} & \multicolumn{2}{|c|}{0.234} & \\
\hline
\end{tabular}

Explanations under Table 2

The application of different doses of the bioorganic fertiliser increased white sugar yield by $13.7-$ $22.9 \%$. The best result was found after application of the highest dose of fertilizer $\left(2 \mathrm{~L} \mathrm{ha}^{-1}, \mathrm{~N}-1-2\right)$. Yield of white sugar increased by $22.9 \%$ and was significantly higher compared with other treatments. Differences between $\mathrm{N}-0.5-2$ and $\mathrm{N}-1-1$ treatments $\left(1 \mathrm{~L} \mathrm{ha}^{-1}\right)$ were little. So, single application of $1 \mathrm{~L} \mathrm{ha}^{-1}(\mathrm{~N}-1-1)$ was the most economically effective treatment compared with double application (N-0.5-2 or N-1-2). In N-1-1 incomes were greater than in $\mathrm{N}-0.5-2$ by $90 € \mathrm{ha}^{-1}$ and only by $20 €$ less than in N-1-2 (data are not presented).

\section{Conclusions}

1. A single application of the bio-organic fertilizer at $1 \mathrm{~L} \mathrm{ha}^{-1}$ dose $(\mathrm{N}-1-1)$ was more effective than $0.5 \mathrm{~L} \mathrm{ha}^{-1}$ or $0.5+0.5 \mathrm{~L} \mathrm{ha}^{-1}$ doses $(\mathrm{N}-0.5-1$ or $\mathrm{N}-0.5-2$ treatments). At the beginning of intensive sugar beet development (BBCH 37-38), the concentration N-1-1 increased the number of leaves by $19.6 \%$, leaf area by $13.4 \%$, root diameter by $11.1 \%$, canopy dry biomass by $29.1 \%$, root biomass by $42.6 \%$, net photosynthetic productivity by $15.8 \%$, root yield by $12.6 \%$, sucrose content by 1.03 percentage units and yield of white sugar by $19.2 \%$ in comparison with the control treatment.

2. Concentration N-1-2 (double $1+1 \mathrm{~L} \mathrm{ha}^{-1}$ rate) showed slightly higher, but not economically suitable results than in singly treated (N-1-1) plots.

3 . As a result, we suggest spraying of sugar beet plants with $1 \mathrm{~L} \mathrm{ha}^{-1}$ dose of nano bio-organic fertilizer once at $\mathrm{BBCH} 18$ growth stage.

Received 06102014

Accepted 06032015

\section{References}

Dewar A. M., May M. J., Waiwod I. P. 2006. A novel approach to the use of genetically modified herbicide tolerant crops for environmental benefit. Proceedings of the Royal Society: Biological Sciences, 270: 35-340

Ghormade V., Deshpande M. V., Paknikar K. M. 2011. Perspectives for nano-biotechnology enabled protection and nutrition of plants. Biotechnology Advances, 29: 792-803 http://dx.doi.org/10.1016/j.biotechadv.2011.06.007

Jakienė E., Slapakauskas V., Mickevičius V., Sapijanskaitė B. 2008. The effect of stilites on the light absorbing ability and productivity of sugar beets. Žemès ūkio mokslai, 15 (2): $32-40$ (in Lithuanian)

Jakienè E., Šlapakauskas V., Brazaitytė A., Sakalauskienė S., Mickevičius V., Duchovskis P. 2009. Effect of liquid complex fertilizers and growth regulators on photosynthesis system indices of sugar beets. Vagos, 85 (38): 14-22 (in Lithuanian)

Kumar S., Bauddh K., Barman S. C., Singh R. P. 2014. Organic matrix entrapped bio-fertilizers increase growth, productivity, and yield of Triticum aestivum L. and transport of $\mathrm{NO}_{3}^{-}, \mathrm{NO}_{2}^{-}, \mathrm{NH}_{4}^{+}$and PO4-3 from soil to plant leaves. Journal of Agricultural Science and Technology, 16 (2): 315-329

Lawlor D. W. 1995. Photosynthesis, productivity and environment. Journal of Experimental Botany, 46 (spec. iss.): $1449-1461$ http://dx.doi.org/10.1093/jxb/46.special issue.1449

Moghaddasi S., Khoshgoftarmanesh A. H., Karimzadeh F., Chaney R. L. 2013. Preparation of nano-particles from waste tire rubber and evaluation of their effectiveness as zinc source for cucumber in nutrient solution culture. Scientia Horticulturae, 160: 398-403 http://dx.doi.org/10.1016/j.scienta.2013.06.028

Naguib A. E. M., El-Baz F. K., Zeinab A., Salama Z. A., Hanaa H. E. B., Ali H. F., Gaafar A. A. 2012. Enhancement of phenolics, flavonoids and glucosinolates of Broccoli 
(Brassica olaracea, var. Italica) as antioxidants in response to organic and bio-organic fertilizers. Journal of the Saudi Society of Agricultural Sciences, 11 (2): 135-142 http://dx.doi.org/10.1016/j.jssas.2012.03.001

Pekarskas J. 2008. Effect of biological preparations biojodis and biokal on yield and chemical composition of organically grow carrots. Sodininkystè ir daržininkystè, 27 (4): 133144 (in Lithuanian)

Pidgeon J. D., Ober E. S., Qi A. 2006. Using multi-environment sugar beet variety trials to screen for drought tolerance. Field Crops Research, 95 (2-3): 268-279 http://dx.doi.org/10.1016/j.fcr.2005.04.010

Romaneckas K., Romaneckienè R. 2009. Leaf-feed fertilizers effect on sugar beet yield and quality. Vagos, 82 (35): 4147 (in Lithuanian)

Sabir A., Yazar K., Sabir F., Kara Z., Yazici M. A., Goksu N. 2014. Vine growth, yield, berry quality attributes and leaf nutrient content of grapevines as influenced by seaweed extract (Ascophyllum nodosum) and nanosize fertilizer pulverizations. Scientia Horticulturae, 175: 1-8 http://dx.doi.org/10.1016/j.scienta.2014.05.021

Salama Z. A., El Baz F. K., Gaafar A. A., Zaki M. F. 2015. Antioxidant activities of phenolics, flavonoids and vitamin $\mathrm{C}$ in two cultivars of fennel (Foeniculum vulgare Mill.) in responses to organic and bio-organic fertilizers. Journal of the Saudi Society of Agricultural Sciences, 14 (1): 91-99 http://dx.doi.org/10.1016/j.jssas.2013.10.004

Shen Z., Zhong S., Wang Y., Wang B., Mei X., Li R., Ruan Y., Qirong Q. 2013. Induced soil microbial suppression of banana fusarium wilt disease using compost and biofertilizers to improve yield and quality. European Journal of Soil Biology, 57: 1-8 http://dx.doi.org/10.1016/j.ejsobi.2013.03.006

Sortino O., Dipasquale M., Montoneri E., Tomasso L., Perrone D. G., Vindrola D., Negre N., Piccone G. 2012. Refuse derived soluble bio-organics enhancing tomato plant growth and productivity. Waste Management, 32 (10): 1792-1801 http://dx.doi.org/10.1016/j.wasman.2012.04.020

Suojala T. 2000. Growth of and partitioning between shoot and storage root of carrot in northern climate. Agricultural and Food Science in Finland, 9 (1): 49-59

Staugaitis G., Laure R. 2008. Leaf-feed fertiliser effect on the yield, quality and profitability of sugar beet. Vagos, 78 (31): 43-47 (in Lithuanian)

Šiuliauskas A., Liakas V., Paltanavičius V., Rauckis V. 2008. The effect of nitrogen fertilizers on the formation of sugar beet yield on soils low in humus. Vagos, 78 (31): 37-42 (in Lithuanian)

ISSN 1392-3196 / e-ISSN 2335-8947

Zemdirbyste-Agriculture, vol. 102, No. 2 (2015), p. 141-146

DOI $10.13080 /$ z-a.2015.102.018

\title{
Bioorganinès nanotrąšos gerina cukrinių runkelių fotosintezès procesą ir produktyvumą
}

\author{
E. Jakiené ${ }^{1}$, V. Spruogis ${ }^{2}$, K. Romaneckas ${ }^{3}$, A. Dautarté2 ${ }^{2}$ D. Avižienytė $\dot{j}^{3,4}$ \\ ${ }^{1}$ Aleksandro Stulginskio universiteto Žemès ūkio ir maisto mokslų institutas \\ ${ }^{2}$ Aleksandro Stulginskio universiteto Aplinkos ir ekologijos institutas \\ ${ }^{3}$ Aleksandro Stulginskio universiteto Agroekosistemu ir dirvožemio mokslu institutas \\ ${ }^{4}$ Lietuvos agrarinių ir miškų mokslų centro Rumokų bandymų stotis
}

\section{Santrauka}

Biologinių medžiagų panaudojimas intensyvina žemès ūkio augalų augimą, todèl jie sparčiau suformuoja maksimalų lapų plotą. Tai optimizuoja fotosintezès procesą, didina augalų produktyvumą ir gerina produkcijos kokybę. Cheminių medžiagų gamintojai sukūrẻ naujos kartos bioorganines trąšas, prisodrintas nanodalelių. Tokios trąšos nèra pakankamai gerai ištirtos, taigi šių tyrimų tikslas - nustatyti bioorganinių nanotrašų, pagamintų iš galvijų mèšlo, tręšimo normų efektyvumą cukrinių runkelių fotosintezès ir produktyvumo rodikliams. Tyrimai atlikti

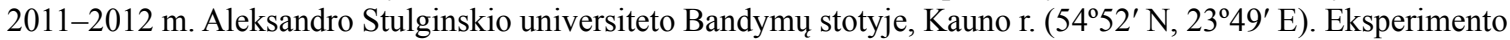
dirvožemis - dulkiško lengvo priemolio giliau glejjiškas karbonatingas išplautžemis (IDg8-k). Cukrinių runkelių augalai buvo purkšti trąšų 0,5 arba $1,0 \mathrm{~L} \mathrm{ha}^{-1}$ dozių tirpalu BBCH 18 ir/ar BBCH 31 vystymosi tarpsniais. Cukrinių runkelių augimo ir produktyvumo rodiklius efektyviau veikè didesnè $1 \mathrm{~L} \mathrm{ha}^{-1}$ vienkartinè dozè trąšų nei vienkartinè $0,5 \mathrm{~L} \mathrm{ha}^{-1}$ arba patręšus du kartus po $0,5 \mathrm{~L} \mathrm{ha}^{-1}$. Palyginus su netręštais runkeliais, cukrinių runkelių intensyvaus vystymosi pradžioje (BBCH 37-38) toks tręšimas esmingai padidino cukrinių runkelių augalų lapų skaičių (19,6 proc.) bei plotą (13,4 proc.), šakniavaisių skersmeni (11,1 proc.), augalų antžeminès dalies sausąją biomasę (29,1 proc.), šakniavaisių biomasę (42,6 proc.), suminị fotosintezès produktyvumą ( 15,8 proc.), šakniavaisių derlingumą (12,6 proc.) bei cukringumą (1,03 proc. vnt.) ir baltojo cukraus derlingumą (19,2 proc.). Dviguba dozè (1+1 $\left.\mathrm{L} \mathrm{ha}^{-1}\right)$ trąšų buvo šiek tiek efektyvesnè, tačiau ekonomiškai mažiau tinkama nei vienkartinè (1 L ha $\left.{ }^{-1}\right)$. Apskritai, tręšimas tirta bioorganine nanotrąša yra efektyvus būdas optimizuoti cukrinių runkelių vystymosi, produktyvumo ir kokybinius rodiklius.

Reikšminiai žodžiai: Beta vulgaris, biometriniai ir augimo rodikliai, cukringumas, derlius. 